7. Solodkyi V.M., Koliada M.I. (2009) Detalna heoloho-ekonomichna otsinka Sakhalinskoho naftohazokondensatnoho rodovyshcha Kharkivskoi oblasti Ukrainy. DP «Poltava RHP», (1), 31

8. Ustenko E.V., Petrunyak V.D., Vyzhva S.A. (2014). Suchasni pohliady na teoriiu vuhlevodnevykh system. KNU im. Tarasa Shevchenka, 59-57.

9. Fedyshyn V.O. (2003) Naukovi zasady otsiniuvannia nyzkoporystykh kolektoriv vuhlevodnevoho hazu. Lviv.

10. Jones F., Davison Ian. Seismic imaging in and around salt bodies. SEG Technical Program Expanded Abstracts 2014. https://doi.org/10.1190/segam20140047.1https://www.britannica.com/science/diapir. .

https://doi.org/10.31713/m1123

\title{
EXPERIENCE IN IMPLEMENTING THE METHOD FOR DETERMINING THE INTEGRATED RISK ASSESSMENT OF ENGINEERING AND GEOLOGICAL PROCESSES FOR THE TERRITORY OF THE VOLYN-PODILSKY PLATE
}

Koshliakov O. Ye.

Doctor of Geological Sciences, Professor,

Head of the Department of Hydrogeology and Engineering Geology, Institute of Geology, Taras Shevchenko National University of Kyiv

Kyiv, Ukraine

\section{Dyniak O.V.}

Candidate of Geological Sciences, Associate Professor of the Department of Hydrogeology and Engineering Geology, Institute of Geology, Taras Shevchenko National University of Kyiv Kyiv, Ukraine

\section{Koshliakova I.Ye.}

Engineer of the Department of Hydrogeology and Engineering Geology Institute of Geology, Taras Shevchenko National University of Kyiv, Kyiv, Ukraine

\section{Summary}

The condition of infrastructure facilities is directly dependent on the engineering and geological conditions of their location. Natural transformations are usually rather slow and are often determined only by consequences. The rate of destruction under the influence of man-made factors significantly exceeds the rate of natural development of the geological object. The main purpose of allocating engineering- 
geological classes (at the regional level) is to identify the most dangerous objects at the local level that require priority engineering intervention. The aim of the study is to identify, map and forecast the patterns and dynamics of negative changes in the geological environment and its main parameters which directly or indirectly affect the state of territories, regions, state as a whole for planning and monitoring the geological environment. The paper proposes an approach to the implementation of the assessment of the state of the geological environment and developed a system of criteria and indicators of assessment, both as a whole and its individual components.

The obtained maps can be used not only to study the conditions of activation and development of hazardous processes, but also for engineering and geological substantiation of measures to prevent and prevent the destruction of foundations and foundations, select priority areas for priority intervention and engineering protection of infrastructure and serve as a basis for planning and monitoring the geological environment.

\section{Introduction}

Today, almost $80 \%$ of the territory of Ukraine is in a man-made state. Urbanization of the country, the creation of powerful mining, hydraulic, reclamation, agro-industrial and other technological complexes, nuclear and thermal power plants have led to a significant increase in man-made loads on the upper geological environment and intensification of exogenous geological processes in the regional plan.

Changes in engineering and geological conditions have developed regionally as a result of intensification of dangerous geological processes - flooding, karst, landslides, reducing the bearing properties of forest soils and swellable clays, subsidence and subsidence of the loess soils due to man-made factors. This process continues to this day. Problems of assessment of engineering and geological conditions (IGC) of territories, activation of dangerous geological processes, issues of studying the conditions of their development have become a number of priority and urgent. The relevance of the research topic is determined by the rapid spread of exogenous processes, both in urban areas and in natural conditions, and the search for ways to predict and prevent them. Despite the decrease in the last 1015 years in the volume of production of some types of minerals, the general ecological condition of the environment in Ukraine as a whole is deteriorating, especially in the mining regions [1].

Due to the underflooding of large areas in Ukraine, the seismic resistance of rock massifs has significantly decreased. Large-scale shifts of the roof in underground workings cause frequent local 
earthquakes. An increasing area is covered by the underflooding process, which is progressing in industrial and urban agglomerations, where there is a significant change in landscapes and there are significant losses from water-bearing communications. In the areas of activity of coal mines, the area of subsidence of the earth's surface above the mine workings exceeds 5 thousand $\mathrm{km}^{2}$. Flooding and water saturation of soils of the aeration zone contribute to the activation of landslides, increase the area of subsidence of loess soils.

The intensification of the karst process removes large areas of developed land from economic development and threatens the functioning of economic facilities in areas of distribution of rocks that are capable of karstification. On the territory of Ukraine with intensive economic activity revealed almost 23 thousand landslides, 26 thousand karst and suffusion-karst formations. It should be noted that out of 429 cities, about $75 \%$ need engineering protection: 244 of them are underflooded; 144 are affected by gravitational processes, 50 are located on subsidence loess soils. Agricultural development of Ukraine is more than $70 \%$, of which plowed land - more than $50 \%$.

Agricultural works are associated with reclamation measures drainage and irrigation, which contribute to the integrated development of several processes: erosion, flooding, salinization, suffusion, karst, subsidence of forest soils and others. A special danger is the development of karst in the areas of sulfur deposits. The development of karst causes the loss of agricultural land and the destruction of buildings. Landslides are taking place on the sides of quarries and sludge storage facilities, which directly threaten settlements. The intensive development of karst associated with the development of potassium salt deposits in Lviv and Ivano-Frankivsk regions is extremely dangerous. Ensuring environmental safety in mining regions is one of the largest and long-term challenges, and therefore requires the development and implementation of appropriate programs.

The complex problem of formation of engineering-geological conditions and their changes under the influence of man-made factors requires the development of scientific bases and scientifically sound comprehensive assessments of these changes and their implementation $[2 ; 3 ; 4]$. 


\section{Methods of integrated assessment of ecological and geological conditions}

Integral assessment of ecological and geological conditions and implementation of zoning of the territory based on the results of studying the individual components of the geological environment is an urgent and quite difficult task.

The IGC assessment is based on the principles of combining geological, historical and environmental approaches, and has the following distinctive features: relativity, special character and specificity. Relativity is due to incomplete knowledge of the studied volume of geological environment, its structure, the processes that control its development. The special nature and specificity stem from the fact that evaluations are always carried out with a fixed purpose. The IGC assessment can be presented in quantitative and qualitative form. As the assessment is detailed, the role of quantitative assessments of indicators increases. In the process of field and laboratory geological research it is possible to obtain more than 200 characteristics of IGC, reflecting the structure, development, properties of the components of the geological environment.

The purpose of integrated assessment is to identify, map and forecast the patterns and dynamics of negative changes in the geological environment (GE) and its main parameters (geochemical, hydrogeological, engineering-geological), which directly or indirectly affect the ecological state of territories, regions, state as a whole, and preparation of a cartographic framework for planning and monitoring the geological environment. One of the main issues of assessing the ecological status of the GE is the development of a system of criteria and indicators for assessing both the geological environment as a whole and its individual components. Without an agreed system of such criteria, it is impossible to perform a reasonable mapping of parameters and characteristics of the geological environment that can be used for ecological-geological or ecological conclusions.

The main task is to collect and systematize the necessary geological, hydrogeological, geochemical, geophysical, ecologicalgeological, etc. information on the materials of previous work and research, the formation of databases of relevant starting and original data, compiling a set of preliminary, auxiliary maps or maps. In modern methodological developments, proposals for the formation of 
criteria for only certain components of the geological environment are often presented. Integral indicators are often far from clear and unambiguous.

When collecting the necessary materials and data, it is necessary to proceed from the position that the accumulated and systematized information should highlight the role and importance of natural and man-made (anthropogenic) factors in shaping the ecological state of the geological environment. Accordingly, data on the state of the geological environment and the factors that determine it can be divided into two groups: natural and man-made.

The first group combines data on climatic, landscape, geological, structural-tectonic, geochemical, hydrological, engineeringgeological, hydrogeological, seismic conditions and pollution of geological components under the influence of natural processes and factors. The second group includes information on man-made objects, sources of environmental pollution and various economic activities, as well as the nature, features, levels of changes in the geological environment under their influence.

The value of different types of information about the natural conditions of the territory, which can be used in assessing the state of the geological environment and solving problems of ecologicalgeological mapping, is determined as follows:

Information on climatic conditions should provide an assessment of the impact of climate on the development of exogenous geological processes, the formation of geochemical characteristics of landscapes, the properties of rocks in the aeration zone, the formation of groundwater (regime, quality). It is recommended to collect information on the following indicators:

- air temperature, its annual fluctuations;

- soil temperature, depth and duration of seasonal freezing;

- humidity (absolute, relative), its annual change;

- the amount of precipitation (annual, average monthly, maximum, minimum, duration of dry and wet periods);

- snow cover (thickness, duration of standing, maximum - minimum for the period of observations);

- long-term trends in temperature, precipitation, snow cover;

- wind rose, predominant directions and speed of air flows;

- state and changes in solar activity. 
Hydrological information should provide an assessment of: the role of the river system in the formation of ecological and geological conditions of the geological environment (landscape, relief, water intake, migration routes of chemical elements and their compounds, etc., features of functional use; hydrodynamic connection of surface and groundwater; and the natural hydrochemical state of surface waters (rivers, reservoirs).

The information includes data on:

- catchment area of major rivers;

- surface watercourses (length, duration of floods and flood areas);

- river runoff (average annual, average monthly water flow, minimum and maximum levels, runoff modulus, flow velocity, longterm trends in flow and water levels);

- natural and artificial reservoirs (water mirror area, depth and volume of water mass, water level regime);

- hydrochemical and qualitative composition, mineralization, salt composition, geochemical relationship between composition, water type and lithological composition of rock complexes);

- the possibility of using surface water for drinking water supply (subject to minimal man-made pollution);

- bottom sediments (lithochemical composition, capacity, nature of distribution in the channel, geochemical characteristics, the presence of sediments that can be used as organic fertilizer in agriculture and other sectors of the economy - type of sapropel);

- bogs (area of distribution, genesis, water supply conditions, capacity of peat and silt).

Information on the state of natural landscapes should be the basis for assessing their importance in the system of ecological and geological conditions of territories, the formation of geochemistry of the modern landscape, definition and interpretation of migration conditions of chemical elements and their compounds. At the same time, such information should be used as a morphogenetic basis of the landscape-geochemical map [5].

Prior to collection, data on:

- types of landscapes (bioclimatic latitudinal-altitude zonation);

- classes of landscapes (composition, nature of soil cover);

- genera of landscapes (groups of genetic types of relief); 
- types of landscapes (paragenetic series or groups of series of Quaternary formations);

- intensity of the biological cycle of chemical elements;

- the nature of physico-chemical migration of elements and their compounds in soils;

- intensity of water exchange and mechanical migration of elements;

- participation of the root substrate in the formation of geochemistry of the modern landscape;

- geochemical specialization of landscapes (natural);

- the ability of landscapes to self-clean;

- biogeochemical provinces and their characteristics.

Geomorphological data is an important component of information used in mapping ecological and geological conditions of the territory, in particular to clarify the position of tectonic faults, decipher neotectonic movements, determine the role of relief elements in migration and concentration of chemical elements and various compounds, substances; distribution and intensity of exogenous geological processes.

Data that characterize or determine are subject to collection and systematization:

- relief morphometry, its vertical and horizontal dismemberment, meso- and microforms of relief;

- density of modern river and ravine network;

- relief structure, its forms and genesis, connection with morphostructural and geological-tectonic factors;

- the influence of relief morphometry on the distribution and intensity of exogenous geological processes;

- influence of relief morphostructure on lateral and vertical migration and concentration of chemical elements, their compounds; substances in solid and liquid state.

Information on soil types, their agrochemical and agrogeochemical features and condition is extremely important for determining, assessing, forecasting ecological and geological conditions of territories. Soils should be considered, on the one hand, as a biomineral substrate for the existence and nutrition of all living things, and, on the other hand, as a sorption barrier that protects groundwater from pollution. Soils are the most sensitive indicator of ecological- 
geochemical and ecological conditions of the territory, because they are located at the intersection of all migration routes of chemical elements and their compounds, including toxic ones. Therefore, they require careful and detailed study of ecological and geological mapping.

Soil information is collected and systematized by the following items:

- main genetic types of soils;

- vertical and horizontal zonation of soils;

- plowing and erosion of soils;

- humus content;

- spotting of soil composition;

- geochemical specialization of soils (associations of chemical elements that can accumulate and elements of removal; leading elements that determine the specialization of soils, geochemical backgrounds of elements, natural geochemical anomalies and fields, geochemical barriers);

- values of biogeochemical transition coefficients in the soil-plant system;

- spatial and genetic connection of geochemical composition of soils with parent rocks;

- sufficient or insufficient supply of soils with macronutrients (phosphorus, potassium);

- sufficient or insufficient supply of soils with micronutrients (manganese, zinc, copper, cobalt, molybdenum, boron);

- threshold values of the content of chemical elements in soils;

- maximum permissible concentrations of pesticides in soils.

Data on the composition, basic properties and characteristics of rocks will allow in combination with other information to fully assess the ecological and geological conditions of a particular area. You need to ensure the collection of data on:

- the nature of the geological section, lithological and petrographic composition of rocks, lithological-facial features of rocks at depths determined by geological tasks;

- mechanical properties of rocks (humidity, cavernousness, porosity, cracking, porosity, mechanical composition, etc.);

- basic stratigraphic-genetic complexes; 
- geochemical specialization of rocks and complexes, individual zones and fields, including aeration zones;

- natural radioactivity of rocks;

- zones with anomalous filtration, migration and gas-geochemical parameters (mercury vapor, radon, methane, etc.);

- geophysical fields (magnetic, gravitational, electromagnetic) and their anomalous zones;

- geopathogenic zones.

Data on the main characteristics and parameters of rocks are supplemented by information on structural-tectonic and neotectonic conditions of the territory, including:

- main tectonic structures and their position, influence on exogenous and endogenous characteristics and conditions of the geological environment;

- zones of compaction, fracturing, crushing of rocks, which can be considered as channels of gas components from the geological subsoil to the surface, and as zones of penetration of pollution into the lower horizons of the geological-hydrogeological section;

- zones of modern tectonic movements and their influence on the distribution and activity of exogenous geological processes (velocities, velocity gradients, total amplitudes of movements); changes in hydrodynamic parameters of groundwater;

- zones of seismogeological activity.

Information on hydrogeological conditions should provide their ecological assessment and ecological-geological mapping.

The following indicators and characteristics are subject to systematization and analysis [6]:

- features of geological and hydrogeological development, distribution and depth of the main aquifer complexes and horizons;

- geological structure and characteristics of the aeration zone (capacity, lithological composition, physical-mechanical and waterphysical properties, the presence of anomalous zones, windows, etc.);

- depth of static levels of groundwater and interstratal waters;

- natural protection of the first from the surface and other aquifers;

- groundwater regime, the nature of changes in time of groundwater levels, major operational and other aquifers and complexes; 
- patterns of changes in the filtration properties of water-bearing and water-resistant rocks in space (in plan and depth); features of filtration (horizontal and vertical) of waters in the aeration zone;

- the main hydrogeological parameters of the water-saturated stratum, which lies above the first regional and local water-resistant layers, and in the case of interconnection - and the underlying aquifers and complexes, especially those used for commercial (drinking) water supply, including filtration and water conductivity, piezoconductivity;

- the direction of regional and local groundwater runoff, the main areas (places) of supply and unloading of groundwater of major aquifers and horizons;

- the relationship of groundwater and interstratal waters, as well as groundwater and surface water, with the definition of modules of groundwater and surface runoff and their changes in space and time;

- the presence of abnormal conditions of nutrition and pollution of groundwater with an assessment of their structure, values and contribution to the overall balance of the aquifer system or its parts;

- changes in mineralization and hydrogeochemical composition of groundwater by area and section (macro- and microcomponents, gas composition, aggressiveness, Eh, $\mathrm{pH}$ );

- spatial parameters of the distribution of temporary ground water and underflooded areas that occur under the influence of man-made activities;

- current state of groundwater resources, groundwater deposits with approved and unapproved operational reserves, which are operated and not operated.

To assess the engineering and geological conditions of territories, the impact of hazardous geological processes and phenomena (exogenous and endogenous) on the ecological state of the geological environment, the following information on exogenous geological processes is required:

- characteristics of areas prone to the development of dangerous processes and phenomena (flooding, karst, landslides, villages, landslides, etc.) under natural conditions;

- assessment of the degrees (levels) of damage to the territory by dangerous exogenous processes and phenomena, determination of natural factors arising from their development and spread; 
- assessment of the spread and development (both in area and depth of the geological section) of dangerous processes and phenomena;

- assessment of the risk of exogenous geological processes and phenomena that can cause significant damage to structures, facilities, various services or lead to catastrophic consequences for endogenous geological processes:

- characteristics of the modern block structure of the territory (macro- and meso-blocks, the direction and speed of their modern vertical movements, the magnitude of the absolute rises and falls of individual blocks and the resulting stresses in the subsoil);

- characteristics of the identified seismogeological zones (zones of natural seismicity);

- characteristics, hazard assessment of seismically generating tectonic zones;

- assessment of the impact of mud volcanism on the increase of seismicity of the territory.

The second group of information indicators, which must be collected and systematized, includes data on:

- functional use of the work area;

- man-made changes (pollution) of the state and quality of the environment, certain components of the geological environment in particular;

- man-made objects and sources of pollution that affect or may affect the ecological state of the environment and the geological environment in particular;

activation of dangerous exogenous and endogenous geological processes and phenomena.

Information on the functional use (zoning) of the territory should characterize:

- modern structure of perspective economic use of the territory;

- zoning of the territory according to the levels of man-caused disturbance of natural landscapes;

- main objects, zones of different types of natural resources that are used or can be used for economic development;

- areas of objects under special protection. 
Information on man-made objects and sources of pollution should determine:

- type, name of the object or source of pollution (enterprises, industries, agriculture, utilities, toxic and radioactive waste storage, solid waste landfills, storage of mineral fertilizers and agricultural chemicals, communication facilities and systems - oil and gas pipelines, railways, highways, canals);

- field of activity or nature of operation;

- administrative position and geographical coordinates;

- time of commissioning of the facility;

- characteristics of industrial waste entering the environment or stored;

- condition or type of insulation of solid waste and various discharges from the environment;

- type of waste - gaseous waste (emissions into the atmosphere), liquid discharges, solid waste;

- volumes (volumes) of waste ( $\mathrm{t} /$ year, $\mathrm{m}^{3} /$ year);

- chemical (geochemical) composition of waste, quantitative content of chemical elements;

- availability of treatment facilities, places of storage and disposal of waste;

- pollution of atmospheric air, groundwater, soil in comparison with current regulations;

- intensification of hazardous geological processes associated with the activities of the enterprise.

Based on the collected data, an inventory of hazardous man-made objects and sources of pollution and a scheme (map) of man-made objects and sources of pollution are compiled.

At the final stage of research, a generalized (integrated) assessment of the ecological state of the geological environment and zoning of the study area, according to the levels of ecological state of the geological environment $[7 ; 8]$.

\section{Methods of integrated assessment of engineering and geologi- cal conditions}

Depending on the natural and economic conditions and the priority tasks to be solved in specific urban areas, the methodological approaches to the assessment of the IGC vary widely. 
Due to the fact that there are no common approaches to such research, the method of integrated assessment of IGC is being developed independently. The selection of calculation systems that characterize the properties of the components of the GE is based on the following requirements: they must be universal; to reflect as much as possible the conditions influencing stability of buildings and constructions; easy to determine on the basis of standard cartographic materials, or easy to deduce on the basis of processing laboratory, experimental, field observations. When estimating IGC, such calculation complexes can be: for relief characteristics - morphometric parameters of relief; to assess the properties of soils - physical and mechanical properties, as well as the conditions of occurrence; for the assessment of groundwater - the conditions of their occurrence and quality composition; to assess geological processes - the type of process, its intensity and the impact of the defined area.

As the IGC integrated assessment for different types of engineering development is detailed, the role of quantitative indicators increases significantly. Given the diversity of IGC and the goals of engineering development of GE, it is almost impossible to offer a single, universal list of calculation systems.

In determining the role of selected calculation complexes in the formation of IGC specific GE and their impact on engineering activities, their ordering is carried out with the determination of the quantitative value of the weighting factor.

To identify the main factors in the formation of IGC and determine the list of settlement complexes, it is advisable to use basic maps that have a common and legitimate content, as well as a way to display the information provided. In order to take into account, the properties of GE components and their degradation under the influence of engineering activities, to determine the category of favorable IGC for engineering development, maps are grouped as follows: soil suitability - geological and engineering-geological; geomorphological conditions - geomorphological and manifestation of geological processes; influence of groundwater - hydrogeological and manifestation of geological processes. The need for grouping of maps is dictated by the procedure of checking the significance of the selected calculation complexes on the main one, which is the basic one. The main requirement for maps is uniformity and display of indicators on 
the basis of which it is possible to make a reasonable selection of areas homogeneous in structure and with a close response to engineering development. To take into account the spatial variability of the IGC, all maps are divided into an equal number of equal squares operational-territorial units. Each of them is assigned an operating index.

Based on the fact that each point of the operational-territorial units has a set of indicators that characterize its properties, and operations with a multidimensional field of indicators are very time consuming, the introduction of an integrated indicator allows to deal with a field of one value that characterizes the whole set of properties. Of course, the integrated indicator should represent as much as possible the variety of states of the components and contain the maximum information about them.

If the area for which the IGC is estimated is quasi-homogeneous in terms of components, then one value of the integrated indicator is obtained. In the case of inhomogeneity of the territory, the integrated indicator for each quasi-homogeneous area is calculated and the model of the field of integrated indicators is rebuilt, which allows to estimate the category of IGC complexity in any part of the modeled territory. For the transition to scalar quantities in the calculation of the integrated indicator used the method of scoring expert assessments. This method is one of the few methods of quantifying indicators that are mostly classified as "qualitative" and their mathematical processing together with quantitative indicators that have different units of measurement. Due to the different level of scientific and methodological development of the selected calculation complexes in the regulatory documentation, each of them was divided into a certain number of conditional points.

The introduction of normalized scores and coefficients of significance reduces the subjectivity inherent in the expert method of solving multicriteria problems. An integral indicator of IGC is the weighted average estimate, which is defined as the sum of the given normalized score estimates of calculation complexes, taking into account the prevalence of the latter in the territory $[9 ; 10]$. 


\section{Basic principles and stages of integrated assessment risk of engineering and geological processes.}

This technique is presented in the form of an algorithm of actions that can be used to study any area, which determines the universality of the development.

To start research in the selected area, you need to have a set of primary information materials. A very important stage of the study is a preliminary analysis of the territory for the presence or absence of engineering and geological processes. At this stage, it is necessary to analyze a set of factors and conditions that determine the probability of occurrence and the degree of activity of each process. The analysis of factors of formation is carried out, as a rule, on the results of monitoring observations for the presence of cases of intensification of processes in the area, stock materials of past research, cartographic materials and meteorological observations in the research area.

Next, the analysis and selection of factors for the formation of engineering and geological processes in the area. A number of factors of formation are analyzed for the presence of a dangerous process and the result is a list of engineering and geological processes specific to the area.

The next stage of the study is to build maps of manifestations of engineering and geological processes types from a number of previously selected. An assessment of the area of existing distribution and the degree of activity of this process, as well as the area of influence of this process during its activation.

Thus, based on the analysis, each type of exogenous processes characteristic of the area, receives a specific parameter and spatial position parameters. Based on this, it is possible to plot the calculated areas on a cartographic geoinformation basis and obtain maps of the distribution (areas of influence) of exogenous geological processes by types. A separate map of its distribution and impact is built for each researched process. The obtained maps of engineering and geological processes manifestations will have a binary type, ie the territory will be divided into several zones, depending on the intensity of the manifestation of the process.

The next step is to directly build risk maps of exogenous geological processes specific to the study area. Using GIS technologies, the plane parameter of the spread of the impact of the dangerous process 
obtained earlier is assigned a score of the intensity of the impact of each type of engineering and geological processes separately. As a result, we obtain a set of risk maps of engineering and geological processes manifestations for each of their types separately.

Next, it is necessary to implement the spatial combination of previously obtained maps. The purpose of summarizing the data is to determine the integrated risk of exogenous geological processes characteristic of the study area. The summary of these risk maps can be performed using the tools of GIS technologies implemented in software packages such as ArcGis and ArcViev. Using automated summation and spatial aggregation algorithms, not only the planar parameter is summed, but also the score for each of the engineering and geological processes types.

Final schematic maps of integrated risk of exogenous processes. is a visual summary of engineering and geological processes risk maps, which shows the imposition of different types of process risks. Map shows the result of summing the score of the intensity of manifestations of exogenous processes in the study area [9;11].

Implementation of the method of determination integrated risk of engineering and geological processes on the territory of Volyn-Podilska plate.

The basis for the construction of cartographic material is information of two types: graphic (positioning of objects in the coordinate system) and attributive (properties of the object). In accordance with the purposes of mapping the areas of presentation of engineering and geological processes manifestations, graphic information can be obtained both by the field mapping method and by processing the results of aerospace surveys.

The main principle in the construction of cartographic material is to determine the area of plots in which the manifestations of engineering and geological processes were recorded. To identify areas with active processes and areas where processes have ever been recorded, monitoring data, information on engineering and geological processes manifestations on Volyn-Podilska plate as technical reports on engineering and geological surveys in the area were used. 
The result of the analysis of engineering and geological processes, characteristic of the study area, was the construction of schematic maps of the following list of natural geological processes:

- landslide processes;

- karst process;

- flooding and inundation processes;

- plane erosion processes.

Thus, after determining the characteristic engineering and geological processes, it is necessary to set the spatial boundaries of the zones within which the presence of a certain process is detected. With the help of the ArcGis 10.1 software package, operations of summation of polygonal objects are determined, which determine the spatial distribution of conditions and factors that determine the manifestation of one or another exogenous geological process.

To further assess the integrated risk of engineering and geological processes, it is necessary to divide the study area into parts of the most representative dimensions, in the scale of cartographic material $1: 3000000$ and the area of the study area $90783 \mathrm{~km}^{2}$ is a cell of $1000 \times 1000 \mathrm{~m}$. The construction of all maps in this work is performed for their further analysis. These notations on the map are not accurate representations of real-world objects and have been chosen for convenience and clarity. Therefore, given these circumstances, the size of the cell $1000 \times 1000 \mathrm{~m}$ is considered sufficient.

The division into elementary cells was performed using the software package ArcGis 10.1, namely GeoWizards (create Vector Grid). Created Vector files, after filling them with attribute information, were converted to Raster files using Conversion Tools (Feature to Raster).

The formed raster images, spatially and geometrically coincide with the studied area. The pixels of this raster image were created in the size of $1000 \times 1000 \mathrm{~m}$ according to the conditional cells.

Since $74.2 \%$ of the territory of Ukraine has widespread rocks in which karst can develop under certain conditions, it was decided to start building maps from this process. The whole territory of VolynPodilska plate is changed by karst formations (Fig. 1). The large karst region is represented by the southern part of Polissya and the Volyn-Podilska Upland, which adjoins it from the south. Affected 
areas of karst landforms range from 0 to 76 units $/ \mathrm{km}^{2}$, the average values are in the range of 4-12 units $/ \mathrm{km}^{2}$. The average area affected is $105.5 \mathrm{~m}^{2} / \mathrm{km}^{2}$ and the volume affected is $57.6 \mathrm{~m}^{3} / \mathrm{km}^{2}$. The average age of the studied karst funnels is 25-40 years. Some forms of 100 , 120 and more than 200 years of age were identified, as well as numerous cases of new failures; the dynamics of the development of the surface karst relief is significantly differentiated by the territory from the rapid leveling of depressive forms and reducing their number to intensify the process with the constant formation of new funnels and depressions.

Within the study area, sub-areas of covered $45 \%$, semi-covered karst $48 \%$ and to a much lesser extent open karst $7 \%$ predominate.

Landslides are the most dangerous exogenous geological processes in Ukraine. Landslides can occur on all slopes, starting with a slope of $19^{\circ}$, but on clay soils and cracked soils, landslides can occur with a slope of $5-7^{\circ}$. They are formed mainly in areas of moist soils, when the force of gravity of the products of rock destruction accumulated on the slopes exceeds the force of soil adhesion. [12]

Landslide processes are intensified in the south of on the territory of Volyn-Podilska plate (Fig. 2).

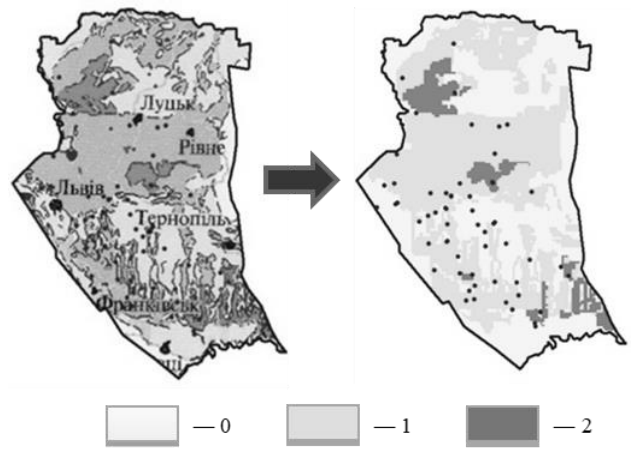

Fig. 1. Map -scheme of karst manifestations on the territory of Volyn-Podilska plate ( 0 - areas of covered karst, 1 - semi-covered karst, 2 - open karst) 


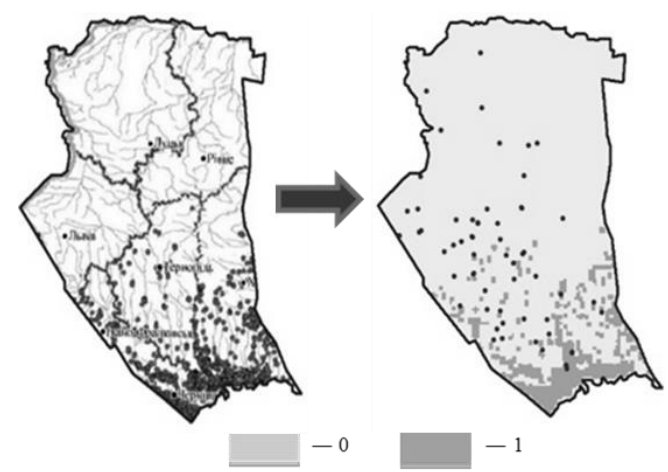

Fig. 2. Map -scheme of the spread of landslides on the territory of VolynPodilska plate ( 0 - no landslides, 1 - development of landslides 1 and 2 categories)

Almost $10 \%$ of the region's territory is affected by landslides, their area is about $908 \mathrm{~km}^{2}$, and the total number is more than 640 landslide-prone areas, $80 \%$ of which are related to economic activities.

Most landslides are concentrated on the right bank of the Dniester River (within Ternopil, Khmelnytsky, Chernivtsi regions). The largest meanders of the Dniester River are dominated by frontal landslides, where there are shifts of considerable size - from several thousand square meters to 13 million $\mathrm{m}^{2}$. It is safe to say that all facilities in the south of the territory of Volyn-Podilska plate are at risk.

Quite large areas of $49 \%$ of the territory of Volyn-Podilska plate have a high degree of subsidence (Fig. 3).

Sedimentary processes are characteristic of areas in the geological structure of which there are connected, often loess soil. To confirm this statement, it is advisable to build a schematic map of cover soils the territory of Volyn-Podilska plate (Fig. 4).

On the territory of Volyn-Podilska plate is dominated by $52 \%$ sand, with inclusions of boulders, and cohesive soils of $27 \%$, represented by moraine-boulder loams. The central part of the territory of Volyn-Podilska plate is characterized by $21 \%$ loess soil. 


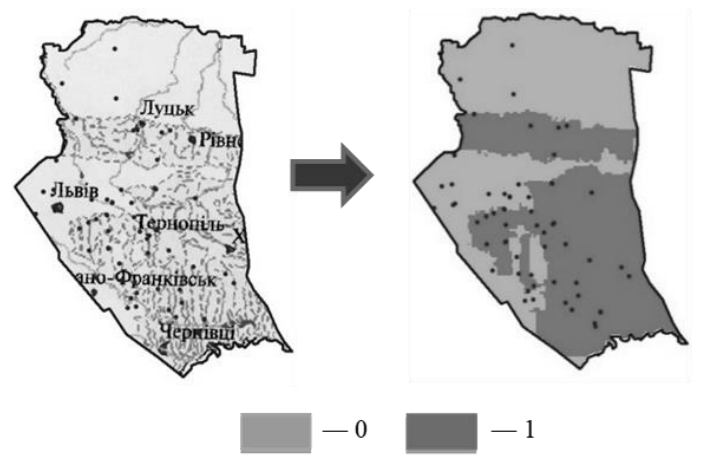

Fig. 3. Map -scheme of subsidence processes on the territory of Volyn-Podilska plate ( 0 - no landslides, 1 - development of landslides 1 and 2 categories)

It is safe to say that the prevalence of cohesive and loess soil has determined the subsidence in the south part of the territory and in its central part.

These soils are waterproof - easily and quickly eroded, soaked, in areas of their distribution are also widely developed ravine-beam formations, rapidly destroying the banks of rivers, lakes, reservoirs, many manifestations of landslides, upflows, solifluction, landslides on the slopes.

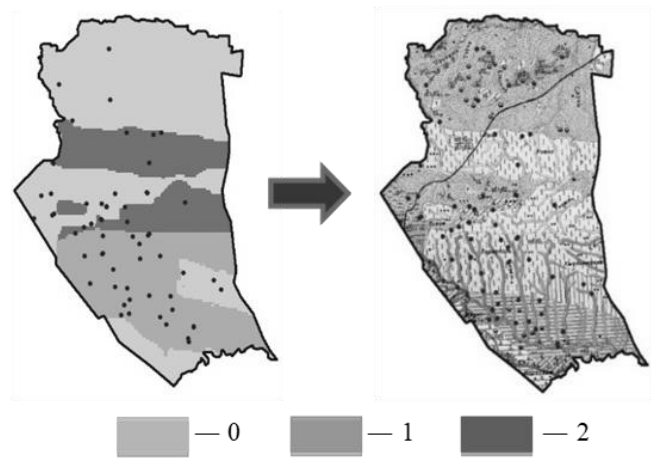

Fig. 4. Map -scheme of cover soils on the territory of Volyn-Podilska plate (0 sandy soils, 1 - cohesive soils, 2- loess soil) 
This geological structure of the territory determines the development of not only subsidence, but also underflooding processes (Fig. 5).

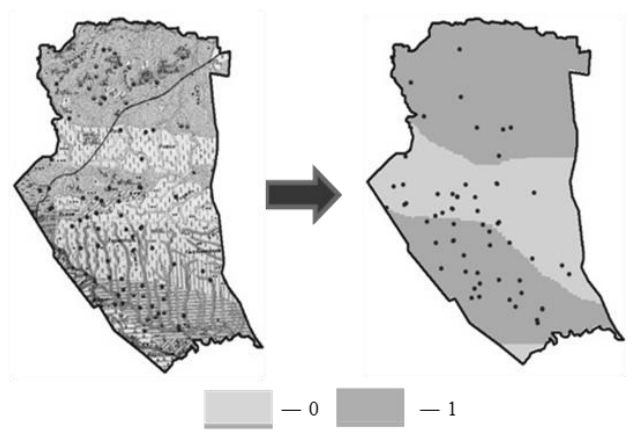

Fig. 5. Map -scheme of underflooding on the territory of Volyn-Podilska plate ( 0 - groundwater depth from the surface $>5 \mathrm{~m}, 1$ - groundwater depth from the surface $<5 \mathrm{~m})$

About $68 \%$ of area the territory of Volyn-Podilska plate is underflooded, with a groundwater depth of $0-5 \mathrm{~m}$ from the surface. In the region the territory of Volyn-Podilska plate and the HalychVolyn basin, the spread of underflooding is observed on the area of 26.03 thousand $\mathrm{km}^{2}, 415$ settlements are underflooded. The largest areas of underflooding were recorded within Rivne (11.7 thousand $\mathrm{km}^{2}$ ) and Volyn regions (9.14 thousand $\left.\mathrm{km}^{2}\right), 216$ settlements are underflooded. Within the rest of the underflooded regions (Lviv, Ternopil and Khmelnytsky) the area of underflooding is 5.19 thousand $\mathrm{km}^{2}, 199$ settlements are flooded. The total area of flooding within the Lviv region alone is 0.25 thousand $\mathrm{km}^{2}$. The total area of underflooding within the Lviv region alone is 0.25 thousand $\mathrm{km}^{2}$.

Underflooding is both natural, sources of flooding - precipitation (melt, flood and rainwater) and man-made. A significant area of underflooding is due to the natural conditions of the territory and is associated with the formation of the region of regional high position of groundwater levels $(0-2.0 \mathrm{~m})$.

The largest areas of flooding are due to mining operations in the Lviv-Volyn basin in the Lviv region. In addition, due to the destruction of sewerage and mine drainage systems and leaching of groundwater toxic components from the rocks of mine dumps, which 
are widely used to fill flooded areas, groundwater has become polluted and unfit for domestic drinking.

Ivano-Frankivsk, Ternopil and Chernivtsi oblasts generally belong to the territories for which the underflooding process is not typical, but flooding areas are also recorded within these territories. It is in the southern part of of Volyn-Podilska plate that partial underflooding is associated with local manifestations of rising groundwater levels.

The position of the groundwater levels deeper than $5 \mathrm{~m}$ allows to refer the areas to areas with a low probability of flooding. Geomorphologically, the Malopolska Upland corresponds to them.

In order to comprehensively assess the impact of engineering and geological processes and phenomena on the current state of geological envairoment within the research area, it is necessary to take into account not only engineering and geological processes that are active, but also factors influencing their activation and further development. In this regard, it is advisable to build the following schematic maps of natural and geological factors:

- map of tectonic movements of the Earth's surface;

- map of erosion of cover soils;

- map of man-caused load;

- map of dynamic impact from main roads;

- and seismicity map.

Tectonics and neotectonics are crucial in the formation of relief and the development of geological processes that affect engineering objects. Endogenous geological processes increase the contrast of the relief and create its most significant forms, respectively - the conditions for the development of exogenous processes. Different direction of tectonic movements contributes to the vertical dismemberment of the terrain and the activation of certain groups of exogenous processes: for areas of uplift - it is erosion, landslides, landslides; for areas of subsidence - flooding, salinization, subsidence of loess soil.

On the territory of the the territory of Volyn-Podilska plateonly in small areas of $21 \%$ there are stable modern movements of the earth's crust (Fig. 6). Such seemingly insignificant areas of active tectonic zones (in the south-west and north) do not ensure the stability of the central part of the the territory. The intensity of 
activation of dangerous exogenous processes depends on the intensity of movements of the earth's crust and can occur in remote areas for thousands of kilometers. It is the spatial differentiation of the velocities of modern movements of the earth's crust that determines the intensity of manifestations of modern geological processes.

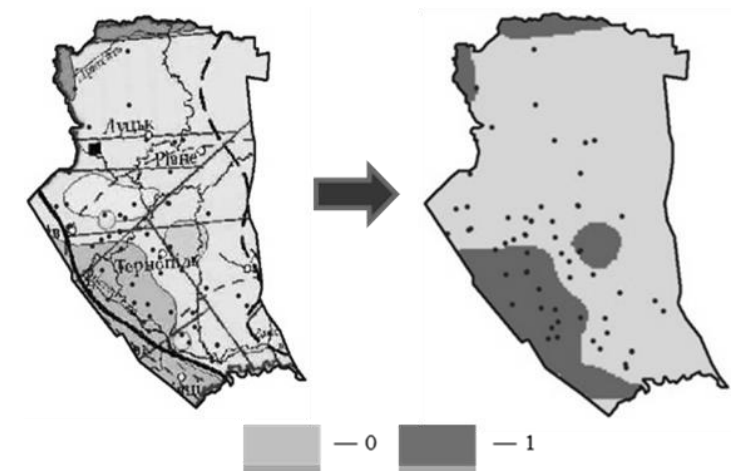

Fig. 6. Map -scheme of of neotectonic movements on the territory of VolynPodilska plate $(0$ - movements are absent or insignificant, 1 - constant modern movements of the earth's crust)

Seismicity is one of the most influential factors that determine the engineering and geological conditions of the territory. The most intense seismic influence is present in the south-western part of Ukraine within the narrow zones of seismically generating deep faults. Until the $70 \mathrm{~s}$ of the twentieth century. It was mistakenly believed that in most of Ukraine, located on the ancient Eastern European tectonic platform, significant seismic events are impossible, so most structures were built without seismic protection measures.

But as we know today, in general up to $40 \%$ of Ukraine can be directly affected by dangerous seismic events and up to $70 \%$ - the combined effects of earthquakes and floods, landslides, subsidence and other engineering and geological processes that adversely affect the stability of structures.

The most intense seismic influence is present in the south-western part of Ukraine. The result of the schematic map of the impact of the Vrancea zone on the study area (Fig. 7) is the following conclusions: $43 \%$ of the the study teretory is in the 6-point impact area, $44 \%-7$ points and $13 \%$ - in the area of possible shocks with an intensity of 8 
points. In addition, local earthquakes can occur in different parts of the Ukrainian Carpathians, the impact of which cannot be ignored either.

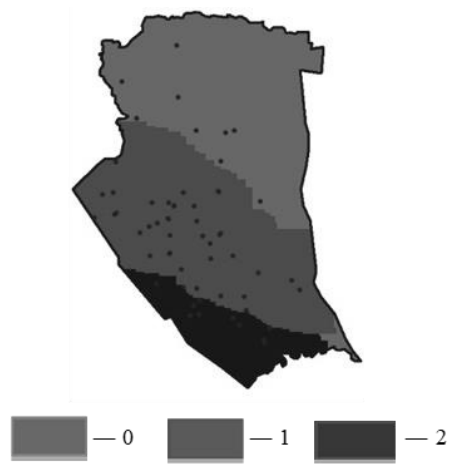

Fig. 7. Map -scheme of seismic activity on the territory of Volyn-Podilska plate (0 - 6 scores, 1 - 7 scores, 2 - 8 scores)

A special factor is man-made (induced) seismicity, which reduces the seismic stability of rocks in the upper zone of the geological section (conditional increase in score). Dynamic loads experienced by geological bodies in wave fields during earthquakes, as well as vibrations from the work of mechanisms and transport, cause changes in physical and mechanical properties of soils and the nature of geological processes, which mainly determines changes in engineering and geological conditions.

That is, in urban areas, in addition to the threat of seismic activity, there is a kind of vibrational background (from roads and highways). Most often during the action of seismic waves there is a decrease in the stability of soils in the foundations of structures, sometimes to a critical state.

Under the influence of man-caused vibrations, certain negative engineering-geological processes (rarefaction, compaction, subsidence) are at the stage of activation or become potentially active, which can cause damage to engineering structures. Vibrational oscillations propagating from highways are transmitted to the soil, affecting their strength properties, and then to the 
foundations of buildings and structures, leading to damage to their structures.

The loss of soil strength under dynamic loads is influenced by a large number of interrelated factors. These are external (parameters of dynamic influence) - acceleration of oscillations, frequency; internal factors - mineral composition, structure, condition, physical and chemical properties; the third group of factors depends on the structure of the array.

The intensity of dynamic oscillations are directly dependent on the intensity of road traffic (Fig. 8). It is logical that the maximum threat is posed by European (E) roads, with maximum road congestion. Ways of international $(\mathrm{M})$ and national $(\mathrm{H})$ connection with less dynamic load within the agglomerations, Lviv, Ternopil, Lutsk, due to their combination create significant dynamic loads on the territories.

Vibrations from transport propagate mainly in the upper part of the soil layer, according to Lokshin up to $10-15 \mathrm{~m}$, because most of their energy is transported by surface Rayleigh waves.

Approximately to these marks the foundations of most buildings and communications are deepened [13].
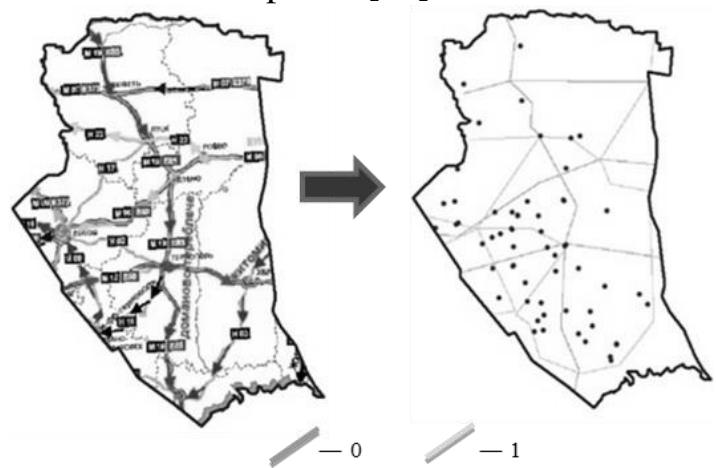

Fig. 8. Map - scheme of highways on the territory of Volyn-Podilska plate (0 ways of international / national communication, 1 - ways of European communication)

Another rather unfavorable process is planar soil erosion. The intensity of erosion depends on a number of factors, the main of which are climatic conditions (precipitation intensity, amount of 
snow cover), terrain, mechanical and structural composition of soils, waterlogging of the territory.

Eroded soils ( $24 \%$ of the total area) can be traced in the south and southwest of the territory of Volyn-Podilska plate. This is due to the terrain, altitude differences increase from north to south, the nature of the soil base, on sandy and structured soils erosion is weaker than on clay, cohesive and poorly structured soild, clays and loams are easily eroded, and seasonal ground water.

The consequences of man-caused impact on the geological envairoment are manifested in changes in mineralogical, geochemical, geodynamic, geomorphological, hydrogeological and engineering-geological nature.

Often the consequences of the above changes are the intensification and development of dangerous geological processes.

In Fig. 9 shows the intensity of the spread of pollution as a consequence of man-made impact on urban areas. Most of the territory of Volyn-Podilska plate, $75 \%$, belongs to halos with aboveaverage pollution levels, of which $10 \%$ have a critical man-made load. It is logical that such territories correspond to the cities and the Chernobyl Exclusion Zone. Since in almost all regions of Ukraine, including the territory of Volyn-Podilska plate, created powerful agro-industrial technological complexes of nuclear and thermal power plants man-made loads on the upper zone of the geological environment is growing and only in small areas $25 \%$ level of manmade load does not exceed average. [14]

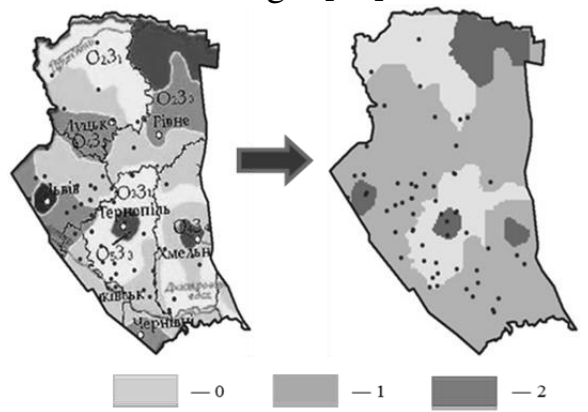

Fig. 9. Map - scheme of the intensity of man-made load highways on the territory of Volyn-Podilska plate ( 0 - pollution below average, 1 - pollution above average, 2 - high pollution) 
The obtained raster images of the territory, with the values of the score coefficient separately, must be summed up using cartographicmathematical algorithms for adding raster images, such as MapAlgebra. The values of the cells that coincide in area location are summed and a matrix of values is formed, ie a new raster layer with a cell size of $1000 \times 1000 \mathrm{~m}$ and the total value of the coefficients of scoring the intensity of detection of the processes under consideration [11].

Thus, the total raster (Fig. 10) is a visual reflection of the result of an integrated assessment of the spread ofengineering and geological processes on the on the territory of Volyn-Podilska plate.

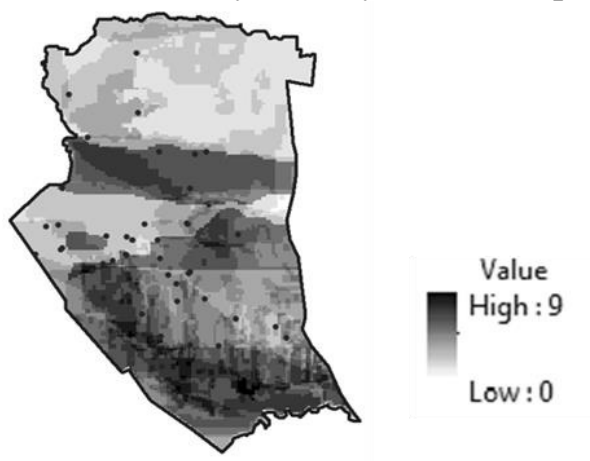

Fig. 10. Map - scheme intensity of manifestations of engineering and geological processes on the territory of Volyn-Podilska plate

According to the results of the study, the area of the territory of Volyn-Podilska plate was divided into 226960 cells measuring $1000 \times 1000 \mathrm{~m}$ with a total area of $567,400 \mathrm{~km}$. The range of permissible cell values is from 0 to 2 , based on a 3 -point rating scale. Valid range of cell values from 0 to 9 .

The given map - scheme (Fig. 9) is auxiliary and overview. The large number of classes makes it inefficient and inconvenient for further use, so the final stage is the process of reclassification and creating a map of the complexity of the engineering and geological processes of the study area.

In Figure 10 shows the resulting schematic map by thinning the area according to the degree of complexity of the engineering and geological condition. Figure 11 shows the final schematic map of the integrated risk of exogenous processes. This shows the result of 
summing the score of the intensity of exogenous processes in the study area and is the resulting schematic map with the ranking of the area according to the degree of risk of engineering and geological processes. This diagram shows the ranking by degree of risk into three classes. First class - less than 3 points, which is a low risk; second - from 3 to 7 points (average degree of risk); third - more than 7 points (high risk).

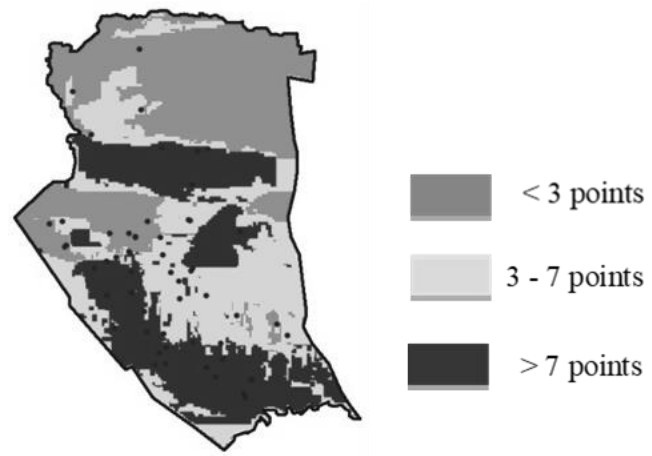

Fig. 11. Map - scheme complexity of engineering and geological conditions on the territory of Volyn-Podilska plate

This scheme reflects the division of the territory into three classes. The first class - less than 3 points, represents rather favorable conditions; the second - from 3 to 7 points (unfavorable); third - from 7 to 9 points (destructive).

The first class - intensity of displays of dangerous geological processes can be carried to neutral - the processes destroying constructions or are absent, or their display on stability of a monument does not influence.

The second class - a combination of dangerous processes in the area is unfavorable, but they develop slowly or a set of processes is not critical.

The third class - areas where the development of engineering and geological processes is complex, maximum and its impact on geological environment can be defined as destructive, it is characterized by a significant area of development of many dangerous processes that develop at a significant rate. 
The main purpose of the allocation of such engineering and geological classes (at the regional level) is to identify the most dangerous objects at the local level that require priority engineering intervention.

From the economic point of view, it is much more expedient to conduct a periodic integrated assessment, which will provide for the intensification and development of hazardous engineering and geological processes and help reduce the cost of protection measures against their impact, than capital restoration work.

\section{Referens}

1. Prusov, D.E. (2015). The methodology for the forecasting consequences of engineering preparation for transformation the urban areas in dense building and complex geology conditions. Proceedings of the National Aviation University, 63, 2. $40-45$.

2. Bondaryk, G.K. (1981) General theory of engineering (physical) geology. Moscow: Nedra. [in Rassian]

3. Gozhyk, P.F., Demchyshyn, M.G., Bida, S.V. (2010). Features of engineering-geological processes in the conditions of urbanized territories. III all-Ukrainian scientific-practical conference "Problems and prospects for the development of academic and university science", Poltava, Ukraine. 9-13. [in Ukrainian]

4. Kril, T.V. (2008). Vibration influence on the geological environment of cities. Geological Journal, 2, 91 - 99. [in Ukrainian]

5. Koshliakov, O., Dyniak, O., Koshliakova, T., Koshliakova, I. (2018). Hydrogelological peculiarities of calculation of scarps and slopes stability within urbanized territories. Visnyk of Taras Shevchenko National University of Kyiv. Geology, 4 (83), 79-83. http://doi.org/10.17721/1728-2713.83.11. [in Ukrainian]

6. Koshliakov, O., Dyniak, O., Koshliakova, I. (2019). Modeling in monitoring system of underground hydrosphere for territories under technogenic pressure. XI International Scientific Conference "Monitoring of Geological Processes and Ecological Condition of Environment", Kyiv, Ukraine. https://doi.org/10.3997/2214-4609.201903232..

7. Veklych, M.F. et al. (1993). Stratigraphic scheme of Quaternary deposits of Ukraine. Kyiv: Hoskomheolohyia. [in Rassian]

8. Richards, L. E. (1986). Conserving geological sites. British geologist, 3 (12), 92-95.

9. Hrokholskyi, N.S. (2013). Methodology for determining the integral risk of exogenous geological processes. Heorysk, 2, 46-47. [in Rassian]

10. Demchyshyn, M.G., Anatskyi, O.M., Kril, T.V. (2007). Information security of entry into protection and preservation of cultural and natural decline. VI International Scientific and Practical Conference - Modern information technologies for environmental safety management, nature management, emergency measures, Kyiv-Kharkiv-Crimea, Ukraine.

11. Dyniak, O., Koshliakova, I. (2021). Experience in the implementation of methods of spatial and system analysis in the study of the geological environment of 
historical sites. International Scientific and Practical Conference "World Heritage Sites: Sustainable Urban Heritage Practices", Kyiv, Ukraine. [in Ukrainian]

12. Exogenous geological processes. SRPE "Geoinform Ukrainy". http://geoinf.kiev.ua/ekzohenni-heolohichni-protsesy

13. Kahan, A. A., Kryvonohova, N.F. (2005). Methodology of geotechnical research in the reconstruction of buildings and structures. Geoekologiya, 3, 275-282.

14. Lomtadze, V.D. (1978). Engineering geology. Special engineering geology. Moscow: Nedra. [in Rassian].

https://doi.org/10.31713/m1124

\section{ESTABLISHMENT OF REGULARITIES OF FLUVIOGLACIAL DEPOSITS AND PROBLEMS OF THEIR EXTRACTION IN THE DEVELOPMENT OF ROCK DEPOSITS OF BUILDING MATERIALS}

Frolov A. A.

National Technical University of Ukraine "Igor Sikorsky Kyiv Polytechnic Institute", Doctor of Technical Sciences, Docent, Professor, Ukraine

\section{Zhukova N. I.}

National Technical University of Ukraine "Igor Sikorsky Kyiv Polytechnic Institute", Candidate of Technical Sciences, Docent, Ukraine

\section{Lytvynchuk I. D.}

National Technical University of Ukraine "Igor Sikorsky Kyiv Polytechnic Institute", PhD Student, Ukraine

\section{Beltek M. I.}

National Technical University of Ukraine "Igor Sikorsky Kyiv Polytechnic Institute", PhD Student, Ukraine

\section{Lukomskyi V. R.}

Taras Shevchenko National University of Kyiv, student, Ukraine

\section{Abstract}

The subject of research in the presented scientific work are the patterns of distribution and features of fluvioglacial deposits on the territory of Ukraine, as well as possible technological schemes and equipment complexes for extraction of fluvioglacial deposits. 